\title{
Quality of Work Life of Police Constables with special reference to Wellness
}

\author{
Dr. Deepti Prashant Lele, Assistant Professor \\ Department of Management, Sinhgad School of Business Studies, Pune
}

\begin{abstract}
The police personnel happen to be the most visible representatives of thegovernment. In an hour of need, danger, or any crisis, people find police to be themost dependable person. The role of police constables is valuable. Besides their assigned dutiespolice constables contribute in disaster management, VVIP duties, guard duties andescort duties, serving of summons and warrants as well as clerical work. They rarelygets holidays and thewelfare facilities they are getting are insufficient.

The researcher has focused only on constable's rank of police personnel. However, police constables are the ones who directly come in contactwith the people in the society. The issues related tohousing facilities and medical facilities problems have been effectivelyexplored .The sample constituted of 630 police constables within the range of five to fourteenyears of service working at police stations under Pune zone. Thus, purposive samplingtechnique was used for data collection. The word wellness covers five areas 1. Physical 2. Welfare facilities 3. Spirituality 4.Economic Condition 5. Emotional . The researcher found that police department provides training programmes on stressmanagement, communication skills, team building and attitudinal change inadequately.
\end{abstract}

Keywords: Inadequate, Police Constable, Pune, Training, Wellness

\section{Introduction}

An alert, capable and brave individual with a badge that adorns his uniform is oftenseen on busy, crowded street. On a closer look, the badge proudly reads: Protectingthe righteous and controlling and annihilating the evil. The police constable therefore, happen to be the most visible representatives of the government. In an hour of need, danger, or any crisis, people find police to be the most dependable person.In any country, the role of police constables is valuable. The police constable rarely gets holidays. Working beyond assigned duty hours, night duties are common thingsto them. But as compare to this the monetary benefits, welfare facilities are inadequate.

\section{Significance of the Study}

In this study the quality of work life of police constables have been examined to get a thorough understanding of wellness of police constables. The results of the study on the promotional avenues and the most important training facilities will guide the policedepartment to enhance the overall quality of constable's work life. The findings will be helpful to understand thework life balance of police constables and thereby prepare an action plan to enhance it.

\section{Literature Review}

Serey (2006), examined the direct and indirect effect of computerization on workers healthand wellbeing. Their results indicated that higher job demands lead to higher strain in workenvironment; hence, it affects workers' health and wellbeing. An unstrained workenvironment ensures good health and psychological conditions which enable the employeesto perform job and non-work related functions without inhibitions. According to theresearcher's observation , duty hours in police department are at least 12 hours.Most of the times the police work for 13-14 hours a day. The job of police is alsorisky .So their job demand leads to higher strain work environment. So it definitely affectstheir health and quality of work.

Sergeant Corey Haines Madison Heights Police Department Madison Heights, MI(2003)designed a comprehensive program to improve the quality of work life forhealthcare staff at a large healthcare organization i.e. staff, physicians, volunteers, andstudents. The quality of work life program at this organization is characterized by threemain components which include social and recognition activities, wellness activities and

awards. Social and recognition activities comprise activities such as golf tournaments,BBQ's, health discipline awareness weeks, and service award celebrations. Wellnessactivities consist of fitness programs, nutrition classes, weight watchers programs,restorative lunch breaks, and random acts of restoration. The various awards include

Nursing Education Awards and Practice Base Research Awards. 
Staff, physicians, volunteers, and students in healthcare who provide services to patientsare very important human resource for any hospital. So somebody should run theseprograms for them on a continuous basis.

Recently in this Ganapati festival the Sakal group has declared the "Tandurust Police program" wherein they provided Chikki and meals to the police personnel. DuringGanpati immersion procession, a large mob from different states, cities comes to Pune towitness the procession. Police have to be alert and their duty hours during such periodscan even stretch upto 48 hours. So they don't get time to have their meals. To avoidthis, the Taniska group, Sakal group and other NGOs came forward to help the policeby initiating this programme.

Khopde (2010) has narrated his initiative in the police department. He introduced a 54points form. At every police station, 3 copies were prepared. One was kept in the policestation, one was handed over to the ACP and another to DGP. It gave clear ideas onabsenteeism, nature, health, family, financial position, religious thinking, social status, 100 job related work and values. Snehabhojan which means taking lunch together once in amonth was another step. It would bring the employees closer and encourage morecommunication among superiors and subordinates. He also introduced cricket matches,kabbadi and plays. Competitions like these between police stations helped divert theattention from small ego problems, politics and internal conflicts. Team work wasencouraged while doing patrolling. He says policemen wander alone without anydirection. A team, if developed the true spirit can fight against any riot or commotion. The police officers will be together during such civic disturbances and can fighttogether. Some can take rest and will take care of each other.

The researcher has observed that so many researchers have thought about differentinitiatives for the police and have documented the same. However the initiatives are nottaken to practical implementation. It is a very difficult task, though not impossible.Sarvankar (2012) has elaborated on the housing facilities for police in Mumbai city.More than 90 percent of the police are living in police quarters under poor conditions. There are no repairs before monsoon. Many police stations and houses are under waterduring flood situations. Now there is a provision of mega housing project in Panvelwhich will provide about 8000 houses for police employees. Out of 50,000 officers inthe police force 30 percent do not have quarters. They have to stay in their own flats orpay rent.186 When the researcher visited different police lines, she observed that therewas a great shortage of water at the lines. There were maximum two rooms in eachhouse. The proportion of number of rooms in the house to number of people staying is1:3. The condition of those chawls was very horrible. The researcher also met onewoman who was staying in Mumbai in one of the police lines as her husband is also apoliceman. She narrated the same conditions of the Mumbai police lines.

Patil,(2011) Minister of State for Home Affairs also admits that police stations need tobe spurred up. They are shabby and do not provide an ideal environment for work. Theinitiatives will be taken to remove disparity in salary and attract more educatedcandidates for police job. The department also intends to intensify training, encourageequal opportunities for both men and women and effectively implement healthcareprogrammes.

Prime Minister, Shri Manmohan Singh(2009) had commented that 80 percent of thepolice personnel belong to the category of constables. They should be provided withadequate housing facility and training to improve their psychological and mental makeup. He feels that they should imbibe the constitutional values of our Republic, respectfor diversity inclusiveness and commitment of secular values.

Wilson, T. (2005, April 30) said that "The higher level of fitness helps the policeexecutive cope with their workload, and we learn about nutrition, diet and themetabolism," It's just another brick in his wall.

Police job is very hectic and it requires them to be physically fit. They should eatnutritious food and exercise everyday to keep fit.

Shain and Suurvali (2001), have acknowledged that the workplace is a majordeterminant of health. They have identified four elements of the workplace that caninfluence the health of employees. The first element, the physical environment, refers toa well designed workplace that promotes employee safety. The second element, thepsychological environment, describes a workplace culture that is supportive andflexible. The third element is personal resources, referring to employees who havecontrol over their work and the resources to do their job. The final element influencingemployee health is identified as personal health practices. This element is described as

the opportunities to make healthy lifestyle choices that contribute to overall health andwell-being. For workplace health promotion to be effective, Shain and Suurvali arguethat it should be comprehensive and aimed at improving each of these elements in waysthat maximize employee wellness.

GP Joshi and JC Arora (1986) tried to find out the progress in the field of policewelfare, to collect and compile information about the type and extent of welfarefacilities made available to police personnel and their family in different states. Datawas collected in May 1985 from Chiefs of all Police forces, as per the recommendation

made by the National Police Commission on the subject of police welfare consisting offollowing areas: Police Housing, Pensionary Benefits, Medical Facilities, EducationalFacilities, Group Insurance and Savings 
Schemes, Resettlement of Retired PolicePersonnel, Special entitlement for Leave, Police Welfare Funds, Police Welfare

officers, Family Welfare-cum-work Centres, Canteens and Cooperative Stores.

Spirituality has been identified as a key component in current research, assisting policeofficers with maintaining their health (Charles, 2005, Feemster, 2008 Smith \& Charles,2010). In this recent research, the participants self reported a strong sense of spirituality.The definition of spirituality for purposes of the research was broadly defined as:Related to meaning, purpose and connectedness to what one considers sacred and howone aligns with that sacredness. This correlates to the concept of spiritual intelligence asidentified by Fontana (2003, p 81) as the ability to be creative, to alter the boundaries ofcurrent thought, to address problems of good and evil, to exercise extended choice, toseek higher meaning in life, and to transform both the self and life situations in positive

ways. This research builds on an earlier study that interviewed 30 law enforcementofficers who reported a strong spiritual basis to their police work.

(Samuel L Feemster 2009) developed a Spirituality in Law Enforcement PracticeModel . In this he stated that Spirituality is the human dimension that shapes lawenforcement practice, performance, vitality, and longevity. This model connectsspirituality with these four areas. Moving from left to right, the model posits thatspirituality is the source of effectiveness for stress management, ethics, emotionalintelligence, and intuitive policing.

Pune Police Public School (PPPS), started in the year 2003, is an English mediumschool under the management of Symbiosis and Pune Citizens' Police Foundation(PCPF). The school is affiliated to the Maharashtra State Board and imparts educationfrom Nursery to Std X. 50\% seats are reserved for children of policemen and $50 \%$ forthe Open students.

Emotional wellness is having the ability to acknowledge and accept a wide range offeelings in oneself as well as in others. It is being able to freely express and manageone's own feelings to develop positive selfesteem in order to arrive at personaldecisions based upon the integration of one's attitudes and behaviours.

Dr.Vidhu Mohan \& Ms. Manpreet Kaur (2013) In their article the duo studied policestress and it remains a constant source of discussion even today, because policepersonnel suffer from various negative stressrelated outcomes. Mental health of policepersonnel is a major concern, because the stressed police personnel behave in ways thatare dangerous not only to them, but also to their colleagues, offenders and public atlarge.

\section{Objectives of the Study}

1. To explore the quality of work life of police constables with a factor wellness.

2. To assess the satisfaction level of police constables.

\section{Research Methodology}

Researcher has concentrated on taking responses of police constables from Pune. Pune Commersionarate is the law enforcement agency with jurisdiction over 790 sq. $\mathrm{km}$.

\subsection{Data}

Primary Data-Primary data was obtained through questionnaire method.

Secondary Data-The secondary data is collected from the different libraries and from online website. A few of these libraries are Centre for Police research, Central Library of Police at Shivajinagar, Sinhgad Institute of Management Library On line information was available on the website of police research centre. i.e. www.bpr\&d.nic.in

\subsection{Sample}

\section{a) Sampling Plan}

Pune City police stations are divided under four Zones, namely Zone I, Zone II, Zone III, and Zone IV. There are total 33 police stations under Pune City. The researcher has collected the data of police constables from all the police stations.

\section{b) Sample Description}

The total population of police constables under Pune Jurisdiction is 3847 . The researcher has taken $16 \%$ of the total population. i.e. 630 police constables. The sample constituted of 630 police constables from Pune lying in range of 5 to 14 years of experience. Thus, purposive sampling technique was used for data collection. 


\subsection{Tools of Data Collection}

1. Questionnaire

5.4 Hypothesis

1. Quality of work life initiatives taken by police department are not satisfactory.

2. Police department provides training programmes on stress management, communication skills, team building and attitudinal change adequately.

\subsection{Scope of the Study}

1) The present study covers police constables having experience of 5 years to 14 years in the police department.

2) The present research has covered all 33 police stations under Pune Commissioner ate.

\subsection{Hypothesis Testing}

\section{Results}

\section{Hypothesis 1: Quality of work life initiatives taken by police department are not satisfactory.}

Table II: Table showing the Chi Square value on opinions of male constable \& female constable on change in duty hours from twelve hours duty to eight hours duty

\begin{tabular}{|l|l|l|l|l|l|l|}
\hline & Accept Completely & Accept to some extent & Cannot Say & Do not accept & Total & Chi Square \\
\hline Males & 276 & 99 & 43 & 44 & 462 & $8.652 *$ \\
\hline Females & 82 & 52 & 13 & 21 & 168 & \\
\hline Total & 358 & 151 & 56 & 65 & 630 & \\
\hline
\end{tabular}

$* \mathrm{p}<.05$. Difference between males and females regarding eight hour duty is significant at .05 level (df 3 ).

Chi square value 8.652 is significant at 0.05 level of significance indicating that there is some association between opinion about eight hours duty and gender. Results show opinions of female constables are not favouring change in duty hours. Supportive evidence has also been derived from content analysis of interviews of police constables. Thus, Hypothesis 1 state that 'Quality of work life initiatives taken by police department is not satisfactory' is accepted.

The researcher spoke with female police constables regarding their dissatisfaction towards eight hour duty. The police constables reported that though there may be reduction in duty hours the timings are inconvenient to them. Police constables are dissatisfied with the reduction in duty hours as the weekly off is laid off. The most important aspect that police constables revealed was that the duty hours of police may be fixed to a certain number of hours. However, in reality working hours of police constables are not fixed. At many occasions the police constables are on duty 24/7. So actually the reduction in duty hours is of no importance to police constables as they are used to irregular working hours.

Hypothesis 2: 'Police department provides training programmes on stress management, communication skills, team building and attitudinal change adequately'.

Table III: Table showing chi square value on the responses of police constables

\begin{tabular}{|l|l|l|l|}
\hline Programs & Yes & No & Chi Square \\
\hline & Frequency (Percent) & Frequency (Percent) & $16.48^{* *}$ \\
\hline Stress Management & $443(70.3)$ & $187(29.7)$ & $16.0^{* *}$ \\
\hline Communication skills & $189(30)$ & $441(70)$ & $8.69^{* *}$ \\
\hline Team Building & $222(35.3)$ & $408(64.7)$ & $8.41^{* *}$ \\
\hline Attitudinal change & $225(35.5)$ & $405(64.5)$ & $12.24^{* *}$ \\
\hline Total & $630(100)$ & 100 & \\
\hline
\end{tabular}

$* * \mathrm{p}<.01$ : Difference significant at .01 level (df 1)

All the chi square values are significant at .01 level of significance. The results show that constables have reported that police department does not organize training programmes on communication skills, team building and attitudinal change. Police constables accept that department conducts training programs on stress management. In the questionnaire the satisfaction regarding training programmes was asked. Satisfaction of police constables regarding stress management was analyzed.

Table IV-35: Table showing chi square value of police constables with respect to their satisfaction on stress management training programme.

\begin{tabular}{|l|l|l|l|}
\hline Programmes & Satisfied & Not Satisfied & \\
\hline & Frequency (Percent) & Frequency (Percent) & Chi square \\
\hline Stress Management & $144(32.5)$ & $299(67.49)$ & $12.24 * *$ \\
\hline
\end{tabular}

**Difference significant at .01 level of significance. 
The Chi square value 12.34 is significant at .01 level of significance (df:1). The results indicate that police constables are not satisfied with stress management training programmes conducted by the police department. Thus, Hypotheses 2 stated as 'Police department provides training programmes on stress management, communication skills, team building and attitudinal change adequately' is rejected. 6.2

Table I: Table showing monthly income of Police Constables

\begin{tabular}{|l|l|l|}
\hline Monthly Income & Frequency & Percent \\
\hline Rs 10000 & 151 & 23.9 \\
\hline Rs 15000 & 279 & 44.4 \\
\hline Rs 25000 & 156 & 24.7 \\
\hline Rs 40000 & 30 & 4.8 \\
\hline Rs 50000 and above & 14 & 2.2 \\
\hline Total & 630 & 100 \\
\hline
\end{tabular}

Table II: Table showing Facilities at the Police Station

\begin{tabular}{|l|l|l|}
\hline Facilities & Yes (Percent) & No (Percent) \\
\hline Drinking water & 87.8 & 12.2 \\
\hline Wash Basin & 54.1 & 45.9 \\
\hline Toilets & 77.3 & 22.7 \\
\hline First Aid & 26.7 & 73.3 \\
\hline Sports Centre & 12.9 & 87.1 \\
\hline Bathrooms & 12.4 & 87.6 \\
\hline
\end{tabular}
condition.

Every police station has the basic facilities at the police station but they are not in satisfactory

Table III: Table showing the satisfaction of police constables regarding facilities available to them at Police

\begin{tabular}{|l|l|l|}
\hline & Stations \\
\hline Yes & Percent & Frequency \\
\hline Partly Yes & 19 & 120 \\
\hline Can not say & 41.2 & 260 \\
\hline No & 35.2 & 29 \\
\hline
\end{tabular}

\section{Findings and observations}

It is observed that the facilities provided to police constables are inadequate. Professional counselling is not available at police station level for alcoholic police constables, police constables having family problems, health problems and psychological disorders. It is also observed that there are only 10 hospitals on the muster of Police Department. The process of reimbursement is also very difficult and lengthy. The police lines are not properly maintained.

\section{8Suggestions:}

A separate rest room for women police constables should be constructed at police stations as per the guidelines of the central government under modernization of police fund. Only providing new technology is not enough. Training should be imparted to everybody in the police station on a continuous basis. On job training is of primary importance. Every policeman and woman at police stations should possess minimum knowledge of cyber crimes, financial frauds, international crimes etc. Spirituality is the human dimension that shapes law enforcement practice, performance, vitality, and longevity. As an invisible weapon, spirituality does not weaken the best aspects of policing; rather, it greatly accentuates them. Spirituality matters to effective practice and performance in seven primary ways.

1) Spirituality nourishes the inner being of officers, inoculating, protecting, and refreshing them from dangerous levels of multiple stressors.

2) Spirituality unleashes vitality by reengaging officers in the spirit of the law.

3) Spirituality heals the deepest, most invisible trauma of wounded warriors.

4) Spirituality provides an antidote for the toxicity of evil, thereby promoting wellness beyond survival.

5) Spirituality nurtures longevity in law enforcement.

6) Spirituality enhances intuitive policing, emotional intelligence, and stress management. 


\section{References}

[1]. Serey, T. "Choosing a Robust Quality of Work Life", Business Forum, 27(2), pp. 7

[2]. Sergeant Corey Haines Madison "Police stress and the effects on the family E.M.U school of police staff and command Heights Police Department Madison Heights, MI An applied research project submitted to the Department of Interdisciplinary Technology as part of the School of Police Staff and Command Program" September 19, 2003

[3]. Taylor, B. 2003, December 24. Fight the flab or face the sack. London Daily Mail, p.34. Retrieved on, from ProQuest database, DOI 513496381, August 22, 2011.

[4]. Sakal 9.09.2013

[5]. Khopde Suresh, Mumbai JalaliBhivandikanahi?, SnehaPrakashan, Pune, p.36.125, 2010

[6]. Sarvankar Nishant, PolisanchaNivasachaprashna, Loksatta, $24^{\text {th }}$ May, 2012, p.1.

[7]. PatilSatej, defines priorities, Protector, Mumbai Police Magazine, vol.2, Issue 3, p. 34, Jan-Feb, 2011

[8]. Singh Joginder, Inside Indian Police, Gyan Publishing House, New Delhi, p. 24, 2009

[9]. The Gold Coast Bulletin, Southport, Queensland, Australia, p. 48. rom ProQuest database, DOI 830318281), August 22, 2011.

[10]. Shain, M. \&Suurvali, H...nvesting in Comprehensive Workplace Health Promotion. National Quality Institute, 2001

[11]. GP Joshi and JC Arora, Welfare Facilities Available to Police Personnel in the Country, Research Studies on Police and Prison Issues (1970 . 2009) - Compendium, 1986

[12]. A PhD thesis by Sergeant Ginger Charles on Policing and spirituality : Their impact on Brain integration and consciousness, Spirituality in the 21st Century: At the Interface of Theory, Praxis \& Pedagogy conference. 20-22 March 2011 in Prague, Czech Republic

[13]. http://wellness.ucr.edu/seven dimensions.html

[14]. Dr.Vidhu Mohan* \& Ms. Manpreet Kaur "Effect of meaningfulness in Life and Stress Resilience on Mental Health of Punjab Police Personnel" Indian Police Journal Jan-Mar 2013

[15]. Ellis N \&PompliA Quality of working life for nurses. Commonwealth Dept of Health and Ageing. Canberra INTERNATIONAL CONFERENCE ON MANAGEMENT (2nd ICM 2012) PROCEEDING ISBN: 978-967-5705-07-6. 2002

[16]. MdSahanur Islam Quality of work life : An insight of causes of attrition in insurance Sector in India ICM 2011 Proceeding

[17]. http://www.cprpune.org

[18]. http:// www.zenithresearch.org.in

[19]. http://www. shodhganga.inflibnet.ac.in

[20]. http://www.bprd.nic.in/

[21]. http://www.punepolice.gov.in 